\title{
Knowledge, awareness and breast-feeding practices of postnatal mothers in a rural teaching hospital: a cross sectional survey
}

\author{
Deepali Ambike1, Abhijit Ambike ${ }^{2 *}$, Swati Raje ${ }^{3}$, Sanjana Chincholikar ${ }^{4}$
}

\author{
${ }^{1}$ Department of Pediatrics, M.I.M.E.R Medical College, Talegaon Dabhade, Pune, Maharashtra, India \\ ${ }^{2}$ Department of Obstetrics and Gynaecology, BK Walawalkar Medical College and Hospital, Dervan, Ratnagiri, \\ Maharashtra, India \\ ${ }^{3}$ Department of Community Medicine, M.I.M.E.R Medical College, Talegaon Dabhade, Pune, Maharashtra, India \\ ${ }^{4}$ II Year MBBS Student, M.I.M.E.R Medical College, Talegaon Dabhade, Pune, India
}

Received: 22 September 2017

Accepted: 27 October 2017

\section{*Correspondence:}

Dr. Abhijit Ambike,

E-mail: aambike@gmail.com

Copyright: (c) the author(s), publisher and licensee Medip Academy. This is an open-access article distributed under the terms of the Creative Commons Attribution Non-Commercial License, which permits unrestricted non-commercial use, distribution, and reproduction in any medium, provided the original work is properly cited.

\begin{abstract}
Background: Breastfeeding has several benefits for both the infants and mothers. Despite the evidence of the protective, immunological and psychological beneficial factors seen in breast milk, a decline in breastfeeding rates has been documented in India. The objective of the present study was to examine the knowledge, attitude and practices in breastfeeding in the postnatal mothers of a rural hospital.

Methods: A cross-sectional descriptive study was carried out among randomly selected postnatal mothers in the postnatal ward of a rural teaching hospital. Data was collected by face to face interviews using a pre-validated structured questionnaire.

Results: Significant difference was found in prevalence of knowledge about advantages of colostrum with respect to education, with less number of people being aware in lower class of education. $\left(\chi^{2}=6.6\right)$ Statistically significant difference was also found in the prevalence of knowledge about advantages of breast feeding with respect to education trend $\left(\chi^{2}=10.48\right)$. No significant association was seen with the knowledge provider (doctor/ relatives) regarding breast feeding practices. Significant difference was found in no. of women with knowledge about breast feeding with respect to parity. Less number of primigravida mothers were aware about advantages of breast feeding compared to multigravida women. $\left(\chi^{2}=4.1\right)$. As against this, more number of primigravida mothers initiated breast feeding within 2 hours compared to multigravida women and difference was statistically significant $\left(\chi^{2}=3.95\right)$.

Conclusions: Our Findings show that prenatal and antenatal education of mothers on initiation of breastfeeding and colostrum along with proper method and techniques of breastfeeding will eliminate the problems and ignorance regarding same. We also recommend involvement of the nursing and social workers in the postnatal ward to encourage and counsel the mothers for proper breastfeeding practices.
\end{abstract}

Keywords: Awareness, Breastfeeding, Knowledge, Mother

\section{INTRODUCTION}

Breastfeeding is a basic human activity, vital to infant and maternal health and of immense economic value to household societies. WHO recommends that for the first six months of life, infants should be exclusively breastfed to achieve optimal growth, development and health. Thereafter, infants should receive nutritionally adequate and safe complementary foods, while continuing to breastfeed up to 2 years or more. Exclusive breastfeeding $(\mathrm{EBF})$ is defined as infant feeding with human milk without the addition of any other liquids or solids. The 
benefits of breastfeeding, to both mother and baby, have long been recognized. Despite strong evidences in support of EBF for the first 6 months of life, its prevalence has remained low worldwide, and it is estimated that only about one third of infants were exclusively breastfed for the first six months of life.

In India, breastfeeding appears to be influenced by social, cultural and economic factors. In 1991, breastfeeding promotion network of India (BPNI) was born to protect, promote and support breastfeeding. Further, the government of India has undertaken National Rural Health Mission, which intends to implement Integrated Management of Neonatal and Childhood Illnesses (IMNCI) through the existing healthcare delivery system. Poor practices and attitude towards exclusive breastfeeding are especially important in developing countries with high levels of poverty, and that are characterized by a high burden of disease and low access to clean water and adequate sanitation.

Although, the practice of breastfeeding is influenced by various social, cultural and religious beliefs, maternal infant feeding attitude has shown to be a stronger independent predictor of breastfeeding initiation. In addition, maternal positive attitudes towards breastfeeding are associated with continuing to be breastfeeding longer and have a greater chance of success. On contrary, negative attitudes of mothers towards breastfeeding is considered to be a major barrier to initiate and continue to breastfeed. While, a number of studies have assessed knowledge, attitude and practice of breastfeeding in different parts of the world; such studies are limited among Indian mothers. ${ }^{1}$

Infant mortality rate (IMR), considered to be one of the most sensitive indicators of the health status of a community, still remains high in India and one of the most important contributory factors is inadequate breastfeeding. According to NFHS-3, $75 \%$ of the children are not breastfed from birth and over $50 \%$ are not exclusively breastfed. Studies in 2008 have shown that breastfeeding promotion alone contributes to $11.6 \%$ reduction in IMR and it reduces the risk of dying from diarrhea and pneumonia.

The benefits of breastfeeding are not just restricted to child, it protects the mother who has breastfed from developing ovarian and premenopausal breast cancers and it also reduces the risk of postpartum bleeding and osteoporosis. $^{2}$

More than $15 \%$ of 24 lakhs child deaths could be avoided in India by optimal breastfeeding practices, but very few women in India have access to counselling services on infant and young feeding. Despite the knowledge of benefits of breastfeeding, its prevalence and duration among general population in many countries are still lower than the international recommendations of 6 months of exclusive breastfeeding. ${ }^{3,4}$ In India it is common practice amongst mothers to extract the initial breast milk which they think is watery and is harmful to the baby. The prevalence of exclusive of six months duration is $46.4 \%$ and the early initiation of breastfeeding practices vary among different regions and communities. ${ }^{3-5}$

Thus, the present study was developed to examine the infant feeding practices, knowledge, and attitude towards breast feeding among Indian postnatal mothers.

\section{METHODS}

This was a cross-sectional study carried out among postnatal mothers who were admitted in our postnatal ward of rural hospital. A structured questionnaire was developed by the pediatricians based on previous experience and review of literature. This was validated and again reformed. All mothers were explained about the purpose of our study. Written informed consent was obtained from the mothers who were ready to participate in the study. Face to face interviews were conducted by the researchers and the local language was used for same.

\section{Inclusion criteria}

- Mothers of neonates born between 37 weeks to 40 weeks gestation

- Mothers of healthy neonates who are not admitted in NICU

- Mothers of babies not with major congenital birth defects.

Institutional Ethical committee Approval was obtained prior to the study.

We surveyed 250 postnatal mothers between the period from January 2017 to June 2017. Data entry done in Microsoft word excels sheet and statistical analysis done by chi square test for the next two months.

\section{RESULTS}

About 250 mothers in the postnatal ward were interviewed and the results tabulated based on their knowledge, attitude and breastfeeding practices. The mothers were of different age groups, educational background and gravida status.

Table 1: Knowledge about advantage of colostrum.

\begin{tabular}{|llll|}
\hline Education & \multicolumn{2}{l}{$\begin{array}{l}\text { Knowledge about } \\
\text { advantage of colostrum }\end{array}$} & Total \\
\hline Below $5^{\text {th }}$ standard & 2 & no & \\
\hline $5^{\text {th }}-10^{\text {th }}$ standard & 55 & 9 & 11 \\
\hline Above $10^{\text {th }}$ standard & 58 & 77 & 132 \\
\hline Total & 115 & 135 & 107 \\
\hline
\end{tabular}


Out of 250 mothers who responded, 115 respondents had knowledge about advantages of colostrum, out of which 55 of them were having education level between 5-10 standard and 58 of them were above $10^{\text {th }}$ standard level. 135 respondents did not have any idea about the advantages of colostrum.

Significant difference was found in prevalence of knowledge about advantages of colostrum with respect to education, with less no. of people being aware in lower class of education. Knowledge increases with increase in education $\left(\chi^{2}=6.6\right)$.

Table 2: Knowledge about advantage of breast feeding.

\begin{tabular}{|llll|}
\hline Education & $\begin{array}{l}\text { Knowledge about } \\
\text { advantage of breast } \\
\text { feeding }\end{array}$ & Total \\
\hline & Yes & No & \\
\hline below $5^{\text {th }}$ standard & 2 & 9 & 11 \\
\hline $5^{\text {th }}-10^{\text {th }}$ standard & 60 & 75 & 132 \\
\hline above $10^{\text {th }}$ standard & 69 & 38 & 107 \\
\hline Total & 128 & 122 & 250 \\
\hline
\end{tabular}

Similarly, out of our 250 mothers who responded about advantages of breastfeeding, only 128 had knowledge regarding same and again 60 of them had $5-10^{\text {th }}$ standard schooling done, and 69 respondents had above $10^{\text {th }}$ standard education. 122 mothers had no knowledge about the advantages of breast feeding.

Statistically significant difference was also found in the prevalence of knowledge about advantages of breast feeding with respect to education trend which was similar to the prevalence of knowledge about advantages of colostrum with respect to education $\left(\chi^{2}=10.48\right)$.

Table 3: Initiation of breast feeding.

\begin{tabular}{|lllll|}
\hline $\begin{array}{l}\text { knowledge } \\
\text { provider }\end{array}$ & $\begin{array}{l}\text { Initiation of breast feeding } \\
\text { (time interval) }\end{array}$ & $\begin{array}{l}\text { T-2 hours } \\
\text { after } \\
\text { delivery }\end{array}$ & $\begin{array}{l}\text { 3 hours- } \\
\text { 1 day }\end{array}$ & $\begin{array}{l}\text { after } \\
\mathbf{1 ~ d a y ~}\end{array}$ \\
\hline Doctors & 39 & 24 & 39 & 102 \\
\hline Relatives & 20 & 15 & 13 & 48 \\
\hline $\begin{array}{l}\text { Doctors } \\
\text { and relatives }\end{array}$ & 52 & 23 & 25 & 100 \\
\hline Total & 111 & 62 & 77 & 250 \\
\hline
\end{tabular}

Out of 250 respondents, 111 of them had initiated breast feeding 1-2 hours after delivery and among them 52 of them had got this information from their doctors and relatives both, 20 from relatives and 39 mothers listened to their doctors. 62 respondents started feeding after 3 hours to 1 day late, out of which 24 of them quoted their doctors and 15 their relatives for same, while 23 listened to both relatives and doctors. 77 respondents started feeding after 1 day, out of which 39 of them said they listened to doctors, 13 to their relatives and 25 to both doctors and relatives.

Out of 250 respondents, 239 mothers had given colostrum and 96 out of them had this knowledge given by their doctors, 45 of them by relatives and 98 by both doctors and relatives. Only 11 mothers had not given colostrum though the knowledge was given to them in 6 by doctors, 3 of them by relatives and for 2 mothers by both doctors and relatives.

Table 4: Colostrum feeds.

\begin{tabular}{|llll|}
\hline Knowledge provider & Colostrum feeds given & Total \\
\hline & Yes & No & \\
\hline Doctors & 96 & 6 & 102 \\
\hline Relatives & 45 & 3 & 48 \\
\hline Doctors and relatives & 98 & 2 & 100 \\
\hline total & 239 & 11 & 250 \\
\hline
\end{tabular}

Out of 250 mothers, only 2 were unaware that prelacteal feeds are not to be given though they said that it was told to them by doctor and relatives which could be their ignorance. 209 mothers were aware that prelacteal feeds are not good to be given and these knowledge providers were doctors and relatives in 87 mothers, only relatives in 37 mothers and in 85 it was doctors who told them. Out of those who gave prelacteal feds were 39 mothers inspite of the education given against it given by doctors to 16 mothers, relatives to 11 mothers and to 12 mothers by both doctors and relatives.

Table 5: Prelacteal feeds.

\begin{tabular}{|c|c|c|c|c|}
\hline \multirow[t]{2}{*}{ Knowledge provider } & \multicolumn{3}{|c|}{ Prelacteal feeds } & \multirow[t]{2}{*}{ Total } \\
\hline & Yes & No & Not aware & \\
\hline Doctors & 16 & 85 & 1 & 102 \\
\hline Relatives & 11 & 37 & 0 & 48 \\
\hline Doctors and relatives & 12 & 87 & 1 & 100 \\
\hline Total & 39 & 209 & 2 & 250 \\
\hline
\end{tabular}

A significant association was observed with the knowledge provider (doctor/relatives) regarding breast feeding practices.

- No. of women who initiated breast feeding at right time (1 hour after delivery) were $111 / 250$ respondents

- No. of women who fed colostrum were 239/250 respondents

- No. of women who did not administer any prelacteal feeds were 209/250 respondents.

Out of 250 respondents of various age groups, 111 initiated feeding within 2 hours of delivery, out of which maximum means 73 mothers were between 21-25 years age, 23 were between 18-20 years age and 15 mothers were above 25 years. Similarly, 62 mothers initiated within 24 hours with majority 32 in age group 21-25 
years age group and 17 between 18-20 years and 13 above 25 years age. Those who initiated after 1 day were 77.

Table 6: Initiation of breast feeding.

\begin{tabular}{|c|c|c|c|c|}
\hline \multirow[t]{2}{*}{ Age } & \multicolumn{3}{|c|}{ Initiation of breast feeding } & \multirow[t]{2}{*}{ Total } \\
\hline & $\begin{array}{l}\text { 1-2 hours } \\
\text { after delivery }\end{array}$ & $\begin{array}{l}3 \text { hours- } \\
1 \text { day }\end{array}$ & $\begin{array}{l}\text { After } \\
1 \text { day }\end{array}$ & \\
\hline 18-20years & 23 & 17 & 19 & 59 \\
\hline 21-25years & 73 & 32 & 38 & 143 \\
\hline $\begin{array}{l}\text { above } 25 \\
\text { years }\end{array}$ & 15 & 13 & 20 & 48 \\
\hline Total & 111 & 62 & 77 & 250 \\
\hline
\end{tabular}

Respondents with majority i.e. 143 in age group 21-25 years age, 48 mothers above 25 years age and 59 of them between 18-20 years age group.

Table 7: Willingness of breast feeding.

\begin{tabular}{|c|c|c|c|}
\hline \multirow[t]{2}{*}{ Age } & \multicolumn{2}{|c|}{$\begin{array}{l}\text { Willingness to } \\
\text { breast feeding }\end{array}$} & \multirow[t]{2}{*}{ Total } \\
\hline & Yes & No & \\
\hline $18-20$ years & 59 & 0 & 59 \\
\hline $21-25$ years & 143 & 0 & 143 \\
\hline above 25 years & 48 & 0 & 48 \\
\hline Total & 250 & 0 & 250 \\
\hline
\end{tabular}

The willingness to breastfeed was seen among all 250 respondents, with 143 mothers in 21-25 years age group, 59 in 18-20 year's age group and 48 mothers were above 25 years.

Knowledge about advantages of colostrum in various age groups was known best in 115 mothers out of which 69 mothers were of 21-25 years age, 23 mothers each fell in below 20 years and above 25 years respectively. 135 mothers had no knowledge at all about advantages of colostrum out of which 74 were between 21-25 years age group, 36 were between 18-20 years age group and 25 mothers above 25 years age group.

Table 8: Knowledge about advantages of colostrum.

\begin{tabular}{|c|c|c|c|}
\hline \multirow[t]{2}{*}{ Age } & \multicolumn{2}{|c|}{$\begin{array}{l}\text { knowledge about } \\
\text { advantages of colostrum }\end{array}$} & Total \\
\hline & Yes & No & \\
\hline $18-20$ years & 23 & 36 & 59 \\
\hline $21-25$ years & 69 & 74 & 143 \\
\hline above 25 years & 23 & 25 & 48 \\
\hline Total & 115 & 135 & 250 \\
\hline
\end{tabular}

Knowledge about advantages of breastfeeding was known to total 128 mothers out of 250 respondents, 69 mothers were between 21-25 age groups, 32 below 20 years and 27 above 25 years. 122 mothers had no knowledge whatsoever, out of which 74 were falling in
21-25 years age group, 27 mothers below 20 years and 21 mothers above 25 years age.

Table 9: Knowledge about advantages of breast feeding.

\begin{tabular}{|llll|}
\hline Age & \multicolumn{2}{l}{$\begin{array}{l}\text { Knowledge about } \\
\text { advantages of breast feeding }\end{array}$} & Total \\
\hline & Yes & No & \\
\hline 18-20 years & 32 & 27 & 59 \\
\hline 21-25 years & 69 & 74 & 143 \\
\hline above 25 years & 27 & 21 & 48 \\
\hline Total & 128 & 122 & 250 \\
\hline
\end{tabular}

Prevalence of knowledge about advantages of colostrum, prevalence of knowledge about advantages of breast feeding in mothers and no of women who initiated breast feeding at right time (1 hour after delivery) did not vary significantly with age of mothers.

Out of 250 respondents, 232 were housewives out of them 93 mothers fed their babies every 2 hourly; 10 , every one hourly; 57 mothers every 3 hourly; 72 mothers fed when baby cried. The remaining 18 mothers were working who came under others category and out of them 99 fed every 2 hourly; 13 , every one hourly; 4 mothers fed every 3 hourly and 5 mothers fed whenever the baby cried. Knowledge about ideal interval of initiating breast feeding had no significant association with occupation of the mothers (housewife/any other).

Table 10: Interval of breast feeding after birth.

\begin{tabular}{|c|c|c|c|c|c|}
\hline \multirow[t]{2}{*}{ Occupation } & \multicolumn{5}{|c|}{$\begin{array}{l}\text { Interval of breast feeding } \\
\text { after birth }\end{array}$} \\
\hline & Hourly & $\begin{array}{l}\text { Every } 2 \\
\text { hours }\end{array}$ & $\begin{array}{l}\text { After } \\
\text { every } 3 \\
\text { hours }\end{array}$ & $\begin{array}{l}\text { When } \\
\text { baby } \\
\text { cries }\end{array}$ & Total \\
\hline Housewife & 10 & 93 & 57 & 72 & 232 \\
\hline Others & 3 & 6 & 4 & 5 & 18 \\
\hline Total & 13 & 99 & 61 & 77 & 250 \\
\hline
\end{tabular}

Out of 250 respondents, 159 mothers were primigravidas and 70 of them had knowledge about advantages of breast feeding whereas 89 did not have any awareness about it. Similarly, out of 91 multigravidas who were included in the study, only 58 had knowledge about advantages of breastfeeding and 33 did not have.

Table 11: Knowledge about advantages of breast feeding.

\begin{tabular}{|llll|} 
Gravida & \multicolumn{2}{l}{$\begin{array}{l}\text { Knowledge about } \\
\text { advantages of breast feeding }\end{array}$} & Total \\
\hline & Yes & No & \\
\hline Primigravida & 70 & 89 & 159 \\
\hline Multigravida & 58 & 33 & 91 \\
\hline Total & 128 & 122 & 250 \\
\hline
\end{tabular}


Out of 250 mothers, 159 were primigravidas and out of them 80 primis initiated feeding within 2 hours, 38 in one day and 41 of them after 1 day. Similarly, out of 91 multigravidas, 31 mothers initiated after 2 hours, 24 mothers in one day and 36 multigravidas after 1 day.

Table 12: Initiation of breast feeding.

\begin{tabular}{|lllll|}
\hline Gravida & \multicolumn{2}{l}{$\begin{array}{l}\text { Initiation of breast feeding } \\
\text { 1-2 hours } \\
\text { after delivery }\end{array}$} & $\begin{array}{l}\text { 3 hours- } \\
\text { days }\end{array}$ & $\begin{array}{l}\text { After } \\
\text { 1 day }\end{array}$ \\
\hline Primigravida & 80 & 38 & 41 & 159 \\
\hline Multigravida & 31 & 24 & 36 & 91 \\
\hline Total & 111 & 62 & 77 & 250 \\
\hline
\end{tabular}

Significant difference was found in no. of women with knowledge about breast feeding with respect to parity. Less number of primigravida mothers were aware about advantages of breast feeding compared to multigravida women $\left(\chi^{2}=4.1\right)$.

As against this, more number of primigravida mothers initiated breast feeding within 2 hours compared to multigravida women and difference was statistically significant $\left(\chi^{2}=3.95\right)$.

\section{DISCUSSION}

This was the first study conducted in our hospital to study awareness and knowledge regarding breastfeeding in the postnatal mothers.

In the present study, all the 250 mothers (100\%) were ready to feed their babies and were feeding already which was a better observation than the NIMHANS Study by Vijayalakshmi et al in which $88.55 \%$ mothers were feeding their babies. ${ }^{1}$ According to the Infant and Young Child Feeding (IYCF, 2006) guidelines, Government of India recommends that initiation of breastfeeding should begin immediately after birth, preferably within one hour. In number study more, number of primigravida mothers initiated breast feeding within 2 hours compared to multigravida women and difference was statistically significant $\left(\chi^{2}=3.95\right)$.

Only $44.4 \%$ of our mothers had initiated feeding within first 1-2 hours after delivery which was again same as of NIMHANS study by Vijayalakshmi et al and more of primigravida mothers did so than the multigravidas. ${ }^{1}$ Present findings were better than the Punjab study by Garg et al in which only $13.5 \%$ mothers put to breast in first 4 hours after delivery. ${ }^{7}$

In the present study, $46 \%$ mothers had awareness about importance of colostrum believed that colostrum was good to feed, and $95.6 \%$ mothers actually fed it immediately to their babies which was a good and close observation to the Manipal University study by Pandey et al where $75 \%$ mothers fed colostrum to their babies and about $90 \%$ had awareness. ${ }^{2}$ Only $51.2 \%$ of our mothers were aware of the advantages of breastfeeding. Significant difference was found in number of women with knowledge about breast feeding with respect to parity. Less number of primigravida mothers were aware about advantages of breast feeding compared to multigravida women $\left(\chi^{2}=4.1\right)$. This observation was contradictory to the Shanghai study by Jiang et al where $99 \%$ of the mothers had awareness. ${ }^{6}$ Prevalence of knowledge about advantages of colostrum in breast feeding women was $46 \%$ in the present study with the primigravidas better off than the multigravidas similar to the Punjab study by Garg and Deepti et al which showed $35.6 \%$ awareness on colostrum. ${ }^{7}$ However our number was less than the Karnataka study by Kavitha et al which had $84.3 \%$ awareness on colostrum. ${ }^{8}$ As against $70 \%$ awareness about breastfeeding in Chandigarh study which also showed $71.9 \%$ mothers were ready to feed colostrum. ${ }^{9}$

The present study showed that the major source of information about colostrum, breast feeding advantages were the doctors and family members/relatives in $41 \%$ cases which was different from the Kolkatta study by Maumita De et al where the majority knowledge providers were relatives $(76 \%)$ whereas in the Tanzania study $61 \%$ had received knowledge from family members. ${ }^{3,10}$

Statistically significant difference was also found in the prevalence of knowledge about advantages of breast feeding with respect to education trend which was similar to the prevalence of knowledge about advantages of colostrum with respect to education $\left(\chi^{2}=10.48\right)$. In the present study which was somewhat similar to an Australian study on mothers by Wen et al. ${ }^{11}$

Knowledge about ideal interval of initiating breast feeding had no significant association with occupation of the mothers (housewife/ any other) in the present study. Prelacteal feeds was not given by majority of them $(83.6 \%)$ which was a welcome observation and not seen in many studies. ${ }^{12}$

\section{CONCLUSION}

The present study reveals that the benefits of breastfeeding were known to $100 \%$ of the mothers but correct duration, intervals and practices were lacking among them. Hence increased awareness, education and counselling programmes by the healthcare workers and nursing staff should be encouraged to improve awareness in the prenatal and antenatal period only. The Obstetricians should become more proactive in this regard while delivering the other routine antenatal services.

\section{Funding: No funding sources}

Conflict of interest: None declared

Ethical approval: The study was approved by the Institutional Ethics Committee 


\section{REFERENCES}

1. Vijayalakshmi P, Susheela T, Mythili D. Knowledge, attitudes and breast-feeding practices of postnatal mothers: A cross sectional survey. Int J Health Sci. 2015: 9(4):364-75

2. Pandey D, Sardana P, Saxena A, Dogra L, Coondoo A, Kamath A. Awareness and attitude towards breastfeeding among two generations of Indian women: a comparative study 2015. PloS one. 2015;10(5):1-9

3. De Maumita, Taraphdar P, Paul S, Halder A. Awareness of breastfeeding among mothers attending antenatal OPD of NRS Medical College. IOSR J Dental Med Sci. 2016:15(2):3-8.

4. Chezem J, Freiscen C, Boettcher J. Breastfeeding knowledge, breastfeeding confidence and infant feeding plans: effects on actual feeding practices. J Obstet Gynecol Nurs. 2003;32:40-7.

5. World Health Organization. Global strategy for infant and young child feeding. Report by the Secreteriat. World Health Organization; 2003.

6. Hong J, Mu Li, Dongling Y, Li Meng Ven, Hunter $\mathrm{C}$, $\mathrm{He} \mathrm{G}$, et al. Awareness, Intention and needs regarding breastfeeding: findings from first time mothers in Shangai, China. Breastfeeding Med. 2012;7(6):526-34.

7. Garg R, Deepti S, Padda A, Singh T. Breastfeeding knowledge and practices among rural women of Punjab, India: a community based study. Breastfeeding Med. 2010;(5):303-7.

8. Kavitha SD. A descriptive study to assess the knowledge and attitude related to breast feeding among primigravida mothers in Bangalore, Karnataka (M.sc Obstetrics and Gynaecology Dissertation): Gold Finch College, Bangalore: submitted to Rajiv Gandhi University Of Health Sciences, Karnataka. 2009

9. Galhotra A, Abrol A, Agarwal N, Goel N, Swami H. Impact of community based awareness campaign on breastfeeding among lactating women in Chandigarh. Internet J Health: 7(1). Available at https://print.ispub.com/api/0/ispub-article/12581

10. Mbwana, Ally H. Exclusive breastfeeding: mothers awareness and healthcare providers, practices during antenatal visits in Myonmero Tanzania: a thesis presented for degree of Master Of Science in Human nutrition at Massey University, Auckland, New Zealand. 2012. Available at: https://mro.massey.ac.nz/handle/10179/3863 Acessed April 4th, 2014

11. Wen LM, Baur LA, Rissel C, Alperstein G, Simpson JM. Intention to breastfeed and awareness of health recommendations: findings from first-line mothers in south west Sydney, Australia. Int Breastfeeding J. 2009;(4):4358-9.

12. Wen LM, Judy M, Rissel C, Baur LA. Awareness of breastfeeding recommendations and duration of breastfeeding: findings from health beginnings trial: Breastfeed Med. 2012:7(4):223-9.

Cite this article as: Ambike D, Ambike A, Raje S, Chincholikar S. Knowledge, awareness and breastfeeding practices of postnatal mothers in a rural teaching hospital: a cross sectional survey. Int $\mathbf{J}$ Reprod Contracept Obstet Gynecol 2017;6:5429-34. 